\title{
A Tradutora de Cristóvão Tezza: uma trama entrelaçada
}

\section{Luciana Ferrari Montemezzo ${ }^{1}$}

(...) o ensaio, a academia, a tese, todos assomam sempre como expressão de um entendimento neutro, transparente, escalpelado, arranca-se a pele para pensar, libera nos Domine da minha presença física e do pecado da existência, extraia-me conclusões (...) (Tezza,

2016: 102)

Resumo: Este artículo buscar establecer una relación dialógica entre la ficción literaria y los estudios de traducción, a partir de la novela $A$ tradutora, del brasileño Cristovão Tezza (1952), publicado en 2016. Teniendo en cuenta la previa información de que el referido autor es especialista en la obra de Mikhail Bakhtin, se discute la imagen del traductor en el Brasil contemporáneo y el rol de las traducciones como resortes del diálogo entre pueblos y culturas. Se propone analizar la novela a partir de las representaciones del discurso y de las prácticas traductorias según lo planteado por Arrojo (1993), Johnson (1998), Berman (2002) y Mittmann (2003). Se considera, en ese sentido, que la protagonista está inserta en el paradigma del sujeto posmoderno, en una sociedad de consumo, según lo propuesto por Hall (2003) y Bauman (2008).

Palabras-clave: Traducción; Proceso Traductorio; Literatura Brasileña; Cristovão Tezza.

Resumo: Este artigo busca estabelecer uma relação dialógica entre a ficção literária e os estudos de tradução, a partir do romance $A$ tradutora, do brasileiro Cristovão Tezza (1952), publicado em 2016. Considerando a prévia informação de que o referido autor é especialista na obra de Mikhail Bakhtin, discute-se a imagem do tradutor no Brasil contemporâneo e o papel das traduções como molas propulsoras do diálogo entre povos e culturas. A proposta é analisar o romance a partir das representações do discurso e das práticas tradutórias de acordo com o postulado por Arrojo (1993), Johnson (1998), Berman (2002) e Mittmann (2003), bem como de sua relação com a interpretação. Considera-se, nesse sentido, que a protagonista insere-se no paradigma do sujeito pós-moderno, em uma sociedade de consumo, de acordo com o que propõem Hall (2003) e Bauman (2008).

Palavras-chave: Tradução; Processo Tradutório; Literatura Brasileira; Cristovão Tezza.

Introdução

1 Doutora em Teoria e História Literária. Professora do Departamento de Letras Estrangeiras Modernas da Universidade Federal de Santa Maria. 
Atividade desde sempre praticada, ainda que de forma rudimentar, e que remonta as origens míticas do mundo, a tradução surge, antes de mais nada, da necessidade de comunicação e entendimento entre os seres humanos espalhados pela Terra. Nesse sentido, é essencial para o estabelecimento do diálogo entre duas pessoas, duas histórias, duas culturas, colaborando para a difusão e circulação de ideias e pessoas ao longo do tempo. Além disso, também é de fundamental para a compreensão do Outro, entendido como o diferente, o estranho a mim. É a partir do reconhecimento das diferenças - culturais, históricas, ideológicas, linguísticas - que o ser humano poderá reconhecer a si próprio, em um processo de espelhamento. Eu sou o que o outro não é. Ou, ainda, eu me identifico com o que o outro é. Para Berman (2002: 17) "a essência da tradução é ser abertura, diálogo, mestiçagem, descentralização. Ela é relação, ou não é nada ${ }^{2}$."

Embora praticada desde sempre, ainda hoje é uma área que carece imensamente de estudos teórico-metodológicos. A partir de então, o que antes era uma simples habilidade profissional levada a cabo por indivíduos bilíngues, passa a ser, paulatinamente, um relevante objeto de estudos. Com o passar dos anos, a disciplina tem se configurado e fortalecido, graças ao trabalho conjunto entre os vários campos de estudos da área de Letras: linguística, linguística aplicada e literatura comparada, fundamentalmente. Desrespeitando as compartimentações que via de regra engessam os currículos de Letras, a Tradução vem ocupando seu próprio espaço no âmbito acadêmico e desestabilizando os saberes estáveis e as certezas absolutas.

Além das reflexões e avanços teóricos, é preciso considerar que o tradutor é, como todos os seres humanos, perpassado por subjetividade e historicidade. Esta afirmação, aparentemente tautológica, visa a ressaltar as contingências do fazer tradutório: um texto traduzido hoje, daqui a dez anos, será traduzido pelo mesmo sujeito de maneira diferente. O sujeito não é mais o mesmo, a língua não é mais a mesma e a história também não será mais a mesma.

As reflexões sobre o ser humano que está por trás do texto e que empresta sua voz a outra voz, a princípio silenciada pela dessemelhança linguística, vem despertando muito interesse. Não apenas no meio acadêmico, mas também no artístico, as figuras do tradutor e do intérprete ${ }^{3}$ tem sido destacadas. Obras literárias como Quem de nós (1953, romance de autoria do uruguaio Mario Benedetti) e Coração tão branco (1992, romance de autoria do espanhol Javier Marías) são exemplos que destacam a singularidade da escrita e da prática tradutórias. O filme $A$ intérprete (2005, dirigido por Sydney Pollak) também é um exemplo da apropriação artística da profissão.

Neles, não somente a posição do tradutor em uma cadeia comunicacional - por vezes conflitiva $^{4}$ - mas também a sua maneira aparentemente confusa de pensar e compreender o mundo. Assim, estabelecem conexões improváveis entre temas e situações, muitas vezes funcionando como elo em sociedades que primam pela incomunicação ${ }^{5}$ e pela fragmentação.

No Brasil, apenas em 2016 - até onde foi possível apurar - surge um romance que dá papel de protagonista ao profissional de tradução: A tradutora, de autoria do ca-

\footnotetext{
2 Itálico do autor.

3 Algumas vezes inadequadamente utilizadas como sinônimos.

4 Como no caso de $A$ intérprete, em que a protagonista trabalha na ONU e se vê involuntariamente envolvida em um segredo de estado.

5 Como acontece nos dois romances.
} 
tarinense Cristovão Tezza. A partir da análise da personagem Beatriz, uma tradutora de "trinta e poucos anos", este trabalho pretende ampliar as discussões acerca das concepções sobre ato de traduzir, suas implicações e sua relevância na sociedade contemporânea, com especial ênfase à realidade brasileira.

\section{O tradutor na contemporaneidade}

Como parte, essencialmente, da imprecisão, o desafio do tradutor é saber caminhar em areia movediça. A certeza de ontem pode ser a dúvida de hoje. A seleção apropriada para um determinado texto/contexto pode se tornar completamente inadequada em outro. E isso não significa erro: cada situação demanda decisões múltiplas e, por vezes, surpreendentes. A própria definição de erro é igualmente instável. Da mesma maneira, os conceitos de fidelidade e original - outrora fundamentais para qualquer estudo - a partir da década de 1990 passaram a ser rediscutidos no Brasil.

Como se pode entrar em contato com um texto, como fazer com que ele fale e se expresse a não ser por intermédio dessa relação muito especial que também chamamos de "leitura"? Contudo, é a um texto supostamente pleno de significados independentes de uma leitura que a tradução deve ser "fiel"; é àquele texto - imaginário e inexistente - supostamente anterior à intervenção de uma interpretação que o tradutor deve ser "fiel". E na frustração associada a essa fidelidade, ao mesmo tempo esperada e impossível, podemos detectar uma das consequências da relação perigosa que o logocentrismo estabelece entre teoria e prática: qualquer tradução será sempre "infiel" em algum nível e para algum leitor, sempre "menor" e sempre "insatisfatória", em comparação a um original idealizado e, por isso mesmo, inatingível. (Arrojo, 1993: 28-29)

As novas reflexões teóricas se difundem, a partir daquele então, nos meios acadêmicos brasileiros. Embora o senso comum ainda siga crendo na intraduzibilidade, na fidelidade e no lugar privilegiado que ocupa o original em relação à sua tradução, na área de Letras observa-se um processo crescente de profissionalização. Mesmo assim, ainda há um número significativo de tradutores que, simplesmente, são fluentes em um par de línguas. Falta-lhes, normalmente, formação em Letras - que é muito mais abrangente do que apenas o conhecimento aprofundado de um par de línguas. Grande parte deste mercado é fomentado por profissionais sem vínculo empregatício, popularmente conhecidos como frila. Outras vezes constitui-se como atividade profissional paralela a outra carreira afim, como a docência, por exemplo.

\section{O autor e sua obra}

Nascido em 1952, Cristovão Tezza é um dos romancistas contemporâneos mais reconhecidos no Brasil. É autor de uma vasta obra literária - Trapo, Aventuras Provisórias, Uma noite em Curitiba, entre outros. Em 2007, recebeu o Prêmio Jabuti - o mais importante da literatura brasileira - pelo romance $O$ filho eterno. A grande repercussão deste romance, considerado um dos dez melhores da primeira década dos anos 2000 pelo jornal O Globo, foi tão contundente que, em 2011, foi adaptado para o teatro, em forma de monólogo. Ainda no esteio da excelente acolhida, o romance que relata os desafios de um pai para compreender a condição de um filho portador de síndrome de Down, foi adaptado para o cinema e lançado em 2016. 
Além de ficcionista, Tezza também esteve ligado à docência universitária. Primeiramente, na UFSC (1984-1986). A partir de 1986, radicou-se em Curitiba, onde foi professor de língua portuguesa na UFPR, tendo produzido ali relevantes trabalhos acadêmicos. Sua tese, "Entre a prosa e a poesia: Bakhtin e o formalismo russo", defendida na USP em 2002, evidencia a união entre a atividade docente e a ficcional. A partir de 2009, a ficção supera a docência, e o autor se demite da universidade para dedicar-se exclusivamente à literatura.

Em sua produção literária dos anos 2000, é possível identificar um certo interesse do autor por personagens designados por suas profissões: O Fotógrafo (2004), O professor (2014) e, finalmente, A tradutora (2016), o que, de certa forma, traz outra novidade na literatura brasileira: o que há por trás das nossas máscaras sociais, frequentemente identificadas por nossas profissões? Estarão de fato todas as categorias profissionais sujeitas a um estilo de vida e pensamento padronizados? Algumas possíveis respostas - se é que se pode almejar tanto - talvez estejam na coletânea de contos, Beatriz, de 2011. A personagem que surge ali é uma professora e revisora de textos, recém divorciada, de 28 anos.

\section{Beatriz: vozes e ecos tradutórios}

O romance começa narrando mais um dia comum na vida de Beatriz: sai do banho pensando na tradução que está em andamento. Como para a maioria dos tradutores, o trabalho intelectual da protagonista é intermitente. Embora os afazeres cotidianos tomem o espaço do trabalho braçal, diante do computador e da pesquisa em livros, dicionários e sites, nunca serão impeditivos para que o tradutor siga trabalhando mentalmente: nas situações mais inusitadas, nos surpreendemos buscando respostas e soluções tradutórias que, muitas vezes, exigem esforços de memória e concentração fora do comum:

Beatriz voltou à mesa com a toalha úmida erguendo uma torre torcida na cabeça - estou atrasada - e retomou imediatamente a tradução, um pensamento filosófico que, herdeiro novato dos estruturalistas franceses, faz desse pessimismo uma ontologia, a sombra da conspiração universal, esse desespero por não perder tempo, Beatriz lembrou, esperando o pão aquecer no forno, a vida é curta e a vida é sonho (...) (Tezza, 2016: 9) ${ }^{6}$

A princípio, a complexa forma de narrar evidencia a presença de duas vozes, pelo menos. A primeira, de um narrador onisciente e a segunda, do autor que está sendo traduzido, Felip T. Xaveste, catalão, que escreve em um "espanhol barroco, florido e retumbante" (Tezza, 2016: 9). O itálico marca os discursos dos interlocutores da protagonista. O texto em processo de tradução evidencia o fluxo de consciência e processo mental que caracteriza o trabalho do tradutor.

Resistiu mais uma vez a levantar-se: trabalhar mais um pouco, aproveitar este silêncio. $A$ virada linguística da filosofia moderna colocou todo o peso da sua ordenação - da fundação terrena básica às nuvens mais altas [cielos??] do pensamento - nas costas da linguagem. (...) o que antes se entendia como uma fábula moral do comportamento humano, uma metáfora da vida, passou a ser a [se converteu na??] impossibilidade radical de se chegar ao real, enredados que estamos para sempre no véu maléfico e insolúvel da linguagem. Jaq Jacques Der Jacques Derrida, talvez o melhor, mais denso e mais completo feiticeiro da

6 Por tratar-se aqui de uma análise das marcações em itálico, as citações da obra seguem a marcação original. 
sofística contemporânea - e subitamente Beatriz lembrou-se da FIFA: eles vão me telefonar para os detalhes do encontro, e sem telefone, eu - e ela desceu ao chão, de quatro, atrás da bateria do telefone destroçado. (Tezza, 2016: 63)

Às duas vozes iniciais soma-se, em seguida, a voz da própria protagonista. A aparente cacofonia de vozes, em que se intermeiam o pensamento de Beatriz, sua tradução para o texto de Xaveste (em itálico), suas dúvidas tradutórias (palavras entre colchetes, seguidas de dois pontos de interrogação) e a voz de um narrador onisciente é paradigmática para avaliar o processo de tradução: em um mundo cada vez regido pelo imediatismo, o cérebro do tradutor trabalha de modo incessante e estabelece conexões que talvez somente outro colega possa avaliar.

Neste caso, não se trata de cacofonia, mas da aplicação prática dos conceitos de polifonia e dialogismo (Bakhtin, 2008), sintonizados com a trajetória acadêmica do próprio autor do romance. Doutor em Literatura, pesquisador do dialogismo de Mikhail Bakhtin - que tão adequadamente serve para analisar as relações estabelecidas entre os vários elos do processo tradutório - Tezza realmente sabe do que está falando. Não se trata apenas, como de costume, de que há um pouco do autor na personagem, e vice-versa. Possivelmente haja, isto sim, muito do pesquisador Tezza em Beatriz, a tradutora.

Além do pensamento de Beatriz, intercalado com seu processo tradutório e pelo narrador onisciente, há também, outra via de narração: a conversa de Beatriz com sua amiga Bernadete, relatando, entre outras coisas, uma aventura amorosa, ocorrida em um fim de semana, com o marido de uma amiga. Diferentemente dos destaques em itálico e entre colchetes, os diálogos com Bernadete não são marcados graficamente. Apenas podem ser identificados pelo tom amistoso e informal e, algumas vezes, pelos travessões. Todas as vozes são, de alguma forma, mediadas pela de Beatriz. A mediação entre vozes é uma das principais características atribuídas aos tradutores. Contudo, graças aos avanços dos estudos na área, hoje pode-se afirmar que traduzir é muito mais do que mediar e transportar mensagens:

Consideramos o processo tradutório como um processo amplo que envolve o autor, o tradutor, os leitores e as condições de produção. Não se trata, portanto, de analisar o ato individual de um tradutor, como a tradução tem sido vista, mas de um processo complexo que não começa nem termina no tradutor. Consideramos o processo tradutório como um processo de relação de sentidos e de produção de discursos, que surge a partir de condições sócio-históricas de produção. (Mittmann, 2003: 203)

A narrativa ficcional incluiu também uma relação mais duradoura e insatisfatória com o escritor Paulo Donetti (também personagem de coletânea de contos de 2011), definido como ególatra e imaturo e com o editor de Beatriz, Chaves, "um falso paulista, nascido em Minas Gerais" (Tezza, 2016: 9). A relação da protagonista com Donetti aparece por primeira vez em Um erro emocional (2012), romance no qual ele é a personagem principal. Em A tradutora, no entanto, o escritor passa a personagem secundário, em franco processo de exclusão da vida de Beatriz. Ao que tudo indica, há entre os dois um relacionamento de dependência intelectual, que algumas vezes sugere abuso emocional. Mais interessado em ter Beatriz disponível para ler seus escritos, Donetti tenta convencê-la a não aceitar a oferta da FIFA de todas as maneiras:

- Paulo Donetti, deixe de ser ridículo. É só um trabalho. Pelo que você diz, parece que vou me candidatar à presidência da FIFA. (...) Um silêncio curto, algo parecido com um soluço: mas é só mais um gole de vinho, ela concluiu. (...) - Desculpe, mas quem começou foram eles. Eles que disseram que o Brasil precisava de um pontapé na bunda. Lembra? Os caras 
chegam aqui e vão cagando regra por onde passam. O tal Jerônimo alguma coisa. Foi agora, em março. (...) - Jérôme Valcke. Mas você não acha que o Brasil precisa mesmo de um pontapé na bunda? Que patriotada ridícula agora é essa?! É um sósia do Paulo Donetti que está falando? (Tezza, 2016: 54)

Uma boa chave para compreender o funcionamento polifônico do texto explicita-se em um relato de Beatriz a Bernadete, sobre a mania que tem Donetti de intrometer-se na sua vida profissional. Neste caso, o namorado pede-lhe explicação sobre sua opção por colocar suas dúvidas entre colchetes, seguidas de dois pontos de interrogação. Sua resposta, além de paradigmática para tratar da multiplicidade de vozes do relato, acaba, também, por revelar seu método de trabalho - seja ele científico ou intuitivo:

(...) as palavras sempre vêm de algum lugar, prontas para o uso, dizia Xaveste agora dois parágrafos antes a respeito do lugar-comum, e Beatriz colocou as duas mãos no rosto para respirar fundo, um truque de infância, feche os olhos, respire fundo e as ideias insistentes e imagens obsessivas saem da cabeça. Eu estou cansada, é muita coisa no cérebro ao mesmo tempo, mas mesmo respirando fundo respondeu mais uma vez mentalmente a Donetti, as duas interrogações são dúvidas que deixo para trás de modo a não atrasar o trabalho, Sim, disse ele, isso eu sei, mas por que duas, uma só não bastava? Não, idiota (isso ela não disse, e sorriu agora de si mesma, estou melhorando), uma só é pontuação normal. No CTRL+F do word basta digitar ?? e eu chego diretamente nas dúvidas, sem passar pelas ? interrogações comuns. (Tezza, 2016: 36)

A estrutura narrativa sugere, além dos discursos dessemelhantes em que está imersa a protagonista, a fragmentação do sujeito da pós-modernidade. Confuso ante um mundo repleto de possibilidades de relações banalizadas, de consumo - que incluem coisas e pessoas - virtuais ou não, este sujeito empreende, não raro, uma frenética busca por algo que não identifica com clareza. A falta de discernimento sobre seus desejos e aspirações pode ser manifestada pela linguagem igualmente fragmenta, como no caso de Beatriz:

Precisamente porque las identidades se construyen dentro del discurso y no fuera de él, debemos considerarlas producidas en ámbitos históricos e institucionales específicos en el interior de formaciones y prácticas discursivas, mediante estrategias discursivas específicas. (Hall, 2003: 18)

Segundo tal perspectiva, uma mesma personagem produz não apenas um discurso, mas vários discursos, conforme a situação em que está inserida: Beatriz vive em um mundo globalizado, regido, em grande parte, pela circulação de informações, em que o papel do tradutor torna-se cada vez mais relevante. Além disso, estes discursos também marcam as diferentes práticas sociais a que a personagem está sujeita, já que modaliza sua linguagem de acordo com o papel que desempenha - seja como profissional, como amiga ou, ainda, como ela mesma, se ainda é possível pensar em tal categoria.

Além dos discursos anteriormente referidos, há ainda um misterioso envelope, posto por baixo da porta do apartamento da protagonista. Inicialmente Beatriz crê tratar-se de uma conta, mas resiste a abri-lo. Fica pensando, enquanto traduz e dá livre vazão ao fluxo de consciência e memórias que habitam sua mente, se deve ou não desvendar o mistério contido naquela simples - mas intrigante - mensagem. Este é um discurso praticamente silenciado ao longo da narrativa, que só vai ser revelado no final do romance. 
Pensando metaforicamente, o silêncio do envelope pode relacionar-se com o silenciamento do tradutor, sobre os não-ditos e as interdições da linguagem, sejam elas conscientes ou inconscientes. $\mathrm{O}$ efeito do silenciamento acaba sendo uma via de mão dupla: ou o tradutor silencia, para deixar falar o autor, ou silencia o autor e faz ecoar sua própria voz, procurando um espaço de diálogo com o seu leitor, em uma tentativa geralmente mal sucedida de dizer "eu estou aqui" ou "eu também existo".

(...) e ela contemplava o envelope branco ainda sem abrir sobre a mesinha, a tradução bastante adiantada e o vazio expectante de duas escolhas, ou apenas acontecimentos não relacionados, porque as coisas não têm sentido imanente nenhum, diz Xaveste, mas o pensamento messianico, de Marx ao papa, precisa imputar-lhe [atribuir-lhe??] um sentido totalitário (...) Seremos todos escravos do "sentido" mas são sempre os outros que o determinam a ferro e fogo. Você não acha ele bom?, perguntou-lhe Chaves (...) e Beatriz disse um sim inseguro e gaguejante - quase explicou que se movia com dificuldade no mundo das opiniões, aliás irrelevantes para quem traduz, no momento da tradução. É que é até bom fazer uma suspensão total de juízo enquanto traduzo - só o autor deve falar, e sempre nas palavras dele, se isso for possível (...) (Tezza, 2016: 38-39)

O desejo de não emitir juízo ante o trabalho, declarado por Beatriz a seu editor, evidencia sua preocupação com as expectativas mais tradicionais acerca do fazer tradutório. Da mesma forma, a inquietação ante a possibilidade de desvendamento da mensagem envelopada também está relacionada ao processo tradutório em seu sentido mais tradicional: o tradutor é o ser iluminado que desvendará o sentido verdadeiro de uma obra. Ou, ao contrário, será o profanador, o traidor, concepção tão bem ilustrada pelo famoso adágio italiano tradutori traditori.

No processo tradutório, é comum a busca em dicionários, enciclopédias, livros de temas específicos e até mesmo de outras traduções já realizadas do mesmo original. Assim, acaba sendo estabelecida uma relação de sentidos que não foi prevista pelo autor do original (...) Recorrendo a esse tipo de discurso, os tradutores geralmente procuram dar garantia ao leitor de que a tradução expõe o verdadeiro sentido expresso pelo autor. (Mittmann, 2003: 67)

Esquece-se, aquele que crê nos conceitos tradicionais que as línguas - assim como as pessoas - são mutáveis e dinâmicas e que, portanto, igualmente são mutáveis os sentidos. Mais do que isso, os sentidos são instáveis e circunscritos ideológica e cronologicamente. Não há, então, como crer na univocidade em tradução, tampouco em sentidos estanques e presos meramente às definições dicionarizadas.

(...) E Beatriz segurou de novo o envelope em branco contra a luz da janela, atrás de uma pista, e súbito voltaram-lhe o tom e a voz de Erik Höwes perguntando se ela se importaria de lhe mostrar a cidade talvez já na quinta-feira - ele havia usado a palavra commitment, compromisso, e Beatriz interrompeu a tradução para conferir agora as outras traduções no google, como se houvesse um sentido secreto em commitment, um som sugestivo em português, cometer (...) (Tezza, 2016: 39)

Embora Beatriz reconheça, ainda que empiricamente, o processo tradutório como constituído de múltiplas vozes, parece tentar conformar-se com a segurança e o conforto da dúvida menos ameaçadora: procura no google um possível sentido secreto para commitment, mas não abre o envelope. Tal opção, metaforicamente, pode significar segurar a própria voz, anular-se diante da possibilidade de sair das sombras. 


\section{Papeis entrecruzados: vida privada e profissional}

Por ocasião dos preparativos para a Copa do Mundo de 2014, Beatriz é convidada para trabalhar como intérprete de um executivo alemão, que vem a Curitiba para inspecionar as infraestrutura da cidade, candidata a sede do evento. Indicada pela "professora Samanta, do Instituto Goethe" (Tezza, 2016: 29), coube a ela apresentar a capital paranaense ao executivo.

(...) Curitiba era uma cidade candidata, mas tudo está indo tão mal, o estádio mais atrasado de todos, que Porto Alegre pode tomar o nosso lugar e receber os jogos previstos para a cidade (...), o que seria uma vergonha para a cidade e para o Estado! Uma cidade com a tradição urbanística moderna e transformadora de Curitiba é incapaz de erguer um estadiozinho no prazo (...) (Tezza, 2016: 29-30)

A ambientação da trama à realidade imediata do leitor, torna-a ainda mais instigante. Tangenciando temas como a corrupção no futebol, com todas as implicações que isto pode supor, o texto de Tezza é um mergulho no cotidiano brasileiro da segunda década do século XXI:

(...) acredite, é como se eu vivesse sob o terror de uma escravidão profissional, fosse perder minha liberdade ao aceitar o dinheiro da empresa do Blatter. Empresa?! - Indignou-se Donetti - aquilo é uma máfia! Ou uma ONU, dependendo do ângulo. (...) Você às vezes é tão tolinha, Beatriz - o mundo inteiro quer trabalhar para a FIFA! Os caras não têm onde enfiar o dinheiro! (Tezza, 2016: 29)

O fato de estar irremediavelmente ligada ao cotidiano mais imediato do leitor, e de falar da contemporaneidade desde dentro, mas com uma interessante perspectiva externa, tem provocado algumas críticas, na sua grande maioria positivas. Como é um romance muito recente, tais críticas têm aparecido, geralmente, em forma de entrevista, sobretudo, em suplementos culturais dedicados à divulgação da literatura brasileira atual.

É aquela velha história: se fôssemos deixar um romance, unzinho só, numa suposta cápsula do tempo a ser encontrada daqui a muitos anos por escafandristas ou extraterrestres, um romance que os fizesse sentir (quem sabe até entender) as questões que nos assolaram nestes tempos brasileiros, a nova obra de Cristovão Tezza, "A tradutora”, podia ser metida lá dentro. Dos mais seguros romancistas em plena produção no país, o catarinense conseguiu tocar em temas que esbarram em qualquer pessoa que tenha vivido por aqui nos últimos anos - mais precisamente em 2014, quando se passa a trama, durante os preparativos para receber a Copa do Mundo. ${ }^{8}$

Embora inserida no mais genuíno espírito da sociedade pós-moderna, nada convencional, portanto, a protagonista evidencia visões tradicionais sobre o trabalho do tradutor (conforme já foi explicitado anteriormente). Esta atitude, provavelmente, está relacionada à pouca formação profissional. Aceita o desafio de ser intérprete, embora reconheça que as atribuições de tradutores e intérpretes não são as mesmas: “(...) Eu quis dizer na hora que não era exatamente uma intérprete, que nunca fiz tradução simultânea, a câmara de

7 Ambas as capitais acabaram sendo escolhidas como cidades-sede dos jogos.

8 http://www.cristovaotezza.com.br/critica/ficcao/f_a_tradutora/p_o_globo_01out16.pdf - acesso em 20/04/2017. 
horrores dos tradutores, aquilo é uma tortura (...)" (Tezza, 2016: 30). Por outro lado, a observação da protagonista sugere inconsequência ante o resultado de seu trabalho. Se aliado ao seu já mencionado interesse financeiro, considerando a possiblidade de trabalhar para a "empresa de Blatter", é possível afirmar que Beatriz deixa-se levar, sobretudo, pelo desejo de realização econômica, outra marca fundamental da sociedade pós-moderna, pragmática e imediatista. Nesse sentido, Beatriz une o mais tradicional e o mais contemporâneo de nossa sociedade por meio da informalidade de seu trabalho.

Dita informalidade é confirmada em sua conversa com o futuro marido de Jussara, a amiga que foi traída. Embora não a considerasse propriamente uma amiga, o affair aconteceu numa casa de praia, enquanto Jussara dormia. A resposta à pergunta "Você trabalha com quê" (..) (Tezza, 2016: 56) é reveladora para a composição da protagonista, em relação ao seu trabalho como tradutora não profissional:

Trabalho com textos. Sou frila. Revisão de teses, algumas traduções, que provavelmente serão meu principal trabalho futuro. ${ }^{9}$ Também dou aulas, eu poderia acrescentar (...). Eu poderia sentir que alguma coisa se instaurou entre nós. Instaurar seria a palavra certa? $O$ Iluminismo estabeleceu [instaurou??], a duras penas, o primado da razão humana como âncora universal ${ }^{10}$ (...) (Tezza, 2016: 56)

Além da especificação do lugar que Beatriz ocupa no campo da tradução, a conversa com seu affair também demonstra o fluxo de consciência a que está sujeito o tradutor, que muitas vezes associa seu trabalho com as atividades cotidianas. Uma palavra usada em situações corriqueiras pode ser a solução para uma dúvida ou, ao contrário, a elaboração de uma pergunta e de uma hipótese ainda não considerada e pesquisada. Da narração de uma memória afetiva, Beatriz passa quase que automaticamente a pensar no texto de Xaveste, ainda por traduzir. Tudo associado univocamente, a partir da memória de uma traição.

Tema fulcral ao longo do tempo nos estudos acadêmicos da área, parcialmente resolvido por meio de pesquisas contemporâneas, a traição na tradução ainda é considerada uma verdade absoluta pelo público não especializado. A partir da discussão sobre a traição latu sensu, Jonhson (1998) estabelece uma interessante analogia entre este tema, de ordem moral, e a dita traição na tradução, de ordem técnica:

Num tempo em que os computadores, as linhas de montagem automatizadas e as fotocopiadoras substituem com vantagem as memórias e as mãos humanas, e quando a linguagem, a ideologia e o inconsciente são habilmente comparados a máquinas das quais somos fantoches, é difícil saber o que fazer com aquela excrescência defensiva chamada consciência. Sob esse ponto de vista, a crise no casamento e a crise na tradução são idênticas. Visto que tanto tradutores como cônjuges assumiram o compromisso de amar, honrar e obedecer, e visto que ambos inevitavelmente traem, o atual questionamento sobre a possibilidade e a desejabilidade do domínio consciente faz com que tais contratos pareçam ilusórios e enganosos desde o princípio. (Johnson, 1998: 27)

Beatriz considera principalmente o retorno monetário, como normalmente acontece entre os tradutores sem formação específica. Ainda assim, enfrenta a oposição de Donetti, seu namorado. "Veja, Donetti: aquilo parecia irresistível (...). Dinheiro não cai do céu,

9 Referência implícita ao incremento do interesse em relação à atividade, devido às trocas culturais do mundo contemporâneo.

10 Os itálicos são do original. 


\section{Conexão Letras}

e um trabalho pela FIFA deve ser bem pago." (Tezza, 2016: 31). Não é possível afirmar se Beatriz tem um objetivo específico para o dinheiro que receberá da FIFA - o assunto jamais é posto em questão. Talvez seja simplesmente para pagar as contas - ou para fazer uma reserva, já que o trabalho de frila é suscetível a altos e baixos, ou se será destinado à realização de um sonho ou projeto pessoal. Seja qual for a mola propulsora que leva a protagonista a assumir a atividade, ainda que não completamente habilitada para tal, ela pode ser compreendida como uma condição de vida:

[...] ninguém pode se tornar sujeito sem primeiro virar mercadoria, e ninguém pode manter segura sua subjetividade sem reanimar, ressuscitar e recarregar de maneira perpétua as capacidades esperadas e exigidas de uma mercadoria vendável. A "subjetividade" do "sujeito", e a maior parte daquilo que essa subjetividade possibilita ao sujeito atingir, concentra-se num esforço sem fim para ela própria se tornar, e permanecer, uma mercadoria vendável. A característica mais proeminente da sociedade de consumidores - ainda que cuidadosamente disfarçada e encoberta - é a transformação dos consumidores em mercadorias (Bauman, 2008: 20).

Do imediatismo oriundo do desejo de consumo, vem a decisão de aceitar a oferta. Seu trabalho consistiria em acompanhar um alto executivo da FIFA, Erik Höwes, que fez questão de dissuadi-la de sua hesitação em trabalhar como intérprete. Em conversa telefônica, o alemão argumenta:

Sim, intérprete, mas informal, quero dizer, no dia a dia - emendou ele como se previsse a reação. - E talvez algum trabalho de tradução, para tirar algumas dúvidas imediatas, não muita coisa. (...) Mas preciso de expediente integral, alguém que me acompanhe - ele frisou, full time - e secretamente ela gostou de ouvir isso. Escapismo. ${ }^{11}$ Viu-se jantando com Herr Erik, ele barrigudo (...) e ela com o enorme cardápio (...) (Tezza, 2016: 30-31).

Aliviada ante o compromisso de uma atividade formal, Beatriz encoraja-se e aceita a proposta de trabalho. Contrariando todas as expectativas, o executivo alemão era jovem, atraente e bem humorado. As conversas entre os dois fluíam com facilidade e os encontros tornaram-se amistosos e agradáveis. O alemão demonstrava saber muito mais do Brasil do que ela previa. Já na chegada, pediu com naturalidade para conhecer um terreiro de umbanda. Surpresa, Beatriz recorre a Bernadete: "Mas por que diabo um alemão batata vai querer frequentar um terreiro de umbanda em Curitiba?!, divertiu-se a amiga, imediatamente animada com a ideia". (Tezza, 2016: 86)

O surpreendente interesse ao sincretismo religioso brasileiro e à umbanda especificamente: "a umbanda é a cara do Brasil" (Tezza, 2016: 37) delineia a personagem estrangeira de duas maneiras aparentemente opostas: por um lado, como igualmente surpreendente e inusitado e, por outro lado, sintonizada com as expectativas em relação ao exotismo brasileiro. Entretanto, a aparente oposição acaba por configurar-se, segundo avança a narrativa, como dimensões complementares entre si: muito mais do que simples curiosidade pelo culto africano, Erik demonstra estar realmente interessado no que se passam nos terreiros. Tanto é assim que Beatriz o acompanha a um deles:

- Eu sou o Mário - disse o jovem inteiro de branco, com a mão estendida. - Você deve ser o Erik? - mas ele olhava para mim, esperando tradução - e você deve ser a Beatriz, não? A

11 Novamente, neste caso, os itálicos são do original. 
Bernadete me disse que vocês viriam hoje. Por favor, fiquem à vontade. $\mathrm{O}$ culto é livre. $\mathrm{Ou}$ para usar a palavra certa, a gira é livre hoje - e ele sorriu. (Tezza, 2016: 105)

O desejo de Erik por conhecer o terreiro de umbanda pareceu justificar-se por uma possível - mas não totalmente comprovada - incorporação do alemão durante a gira. Como não era praticante da religião, Beatriz não soube precisar a Bernadete se o fato realmente acontecera: “(...) mas só me diga, Bea, baixou mesmo o santo nele?! - e Beatriz disse que sim, pelo menos parecia, mas que armas temos para acreditar em alguém?” (Tezza, 2016: 107)

Além de remeter a um elemento fundamental da formação identitária brasileira, a referência à umbanda, inserida em um contexto que discute a tradução e seus atores, também pode ser considerada uma referência à possibilidade de entendimento entre as diferenças. À primeira vista, seria uma espécie de saudação à cultura brasileira, "o que é misturado é bom" (Tezza, 2016: 106), que destacaria a harmonia racial e cultural do país. Por analogia, seria possível, portanto, pensar no processo tradutório como um processo de mestiçagem, de mistura de elementos e influências e em confluência de vozes. Não há línguas nem culturas puras, não há tradução sem interferência humana, ou dito de outro modo, o tradutor não é um médium, que empresta seu corpo e sua boca - seu cavalo - para que outro fale através de si. "Você não quer um passe também, querida? Parece que... Não não não ${ }^{12}$, ela repetiu, sorridente, mas tensa, eu sou apenas uma tradutora, e naquele momento a palavra parecia definir a sua vida, não seu trabalho. Uma tradutora." (Tezza, 2016: 119)

A convivência entre Beatriz e Erik, intensificada pela atividade de interpretação proporcionou momentos privados que acabaram levando, aos poucos, à intimidade. A conversa comum no restaurante, depois de cumpridos os compromissos do dia, foi deixando de lado o tom formal. " $-\mathrm{E}$ do que você gosta mesmo? - ela arriscou a pergunta (...) - Do que eu gosto? Ah, uma pergunta difícil. De vinho. - e ela acompanhou o sorriso, deixando antever uma sombra de decepção pela piadinha fácil, não espere muito dele." (Tezza, 2016: 115).

$\mathrm{Se}$, de início, aceitar o trabalho parecia ser apenas uma oportunidade de ser "uma tradutora padrão FIFA" (Tezza, 2016: 53), a ideia acabou sendo muito mais que isso, uma vez que retirou Beatriz do seu caótico mundo mental. Antes oscilando entre a obrigação de atender às necessidades da relação falida com Donetti e a urgência do prazo de entrega da tradução de Xaveste, Beatriz pode, em companhia de Erik, fugir de sua rotina e circular em outros ambientes. Não esteve apenas em reuniões importantes - procurando ser o mais discreta possível "ninguém vê um intérprete, são figuras invisíveis, sombras" (Tezza, 2016: 156), mas também em restaurantes e pontos turísticos de Curitiba. Não se pode dizer que estes ambientes lhe seriam restritos, contudo, não é possível considerar, por outro lado, que fizessem parte da sua rotina, uma vez que o trabalho do tradutor é restrito a espaços internos, geralmente claros e silenciosos. Além disso, é um trabalho que pressupõe pouca interação real. Os diálogos se estabelecem muito mais em âmbito textual do que propriamente real. É muito fácil, para um tradutor em processo de trabalho, "conversar" com o texto do que com outro ser humano. Apesar disso, Beatriz tentava manter o controle da situação e organizar seu tempo com vistas a resolver todas as suas pendências:

(...) Erik insistiu: Amanhã cedo você não quer mesmo tomar café comigo no hotel? Podemos conversar e adiantar com calma o roteiro do dia em Curitiba. (...) - Obrigada, Erik. Mas eu realmente tenho um trabalho a terminar amanhã cedinho, estou com o prazo estourado. Podemos marcar às dez? Eu espero você no hall. Já fiz um roteirinho de visitas turísticas, como você pediu. E a previsão do tempo é boa: sol com poucas nuvens. (Tezza, 2016: 125)

12 Marca extrema de oralidade e contemporaneidade, utilizada para dar ênfase na negação. 
Embora tenha se deixado guiar pela máxima feminina "nunca vá para a cama com um homem na primeira noite" (Tezza, 2016: 125), Beatriz acaba por se envolver com Erik e no dia seguinte se dá conta de que Erik é casado:

(...) Erik ressonava, tranquilo como uma criança - e, naquela suíte enorme de onde se via quase que Curitiba inteira (...) encontrou o notebook aberto e sentiu uma compulsão de moleque de tocar o touchpad e revelar a imagem do monitor adormecido (...) esta imagem revela as pessoas, Chaves the disse (...) o que você escolhe para pôr ali é o que você é. (...) será que realmente eu esperava que Erik fosse um caso a levar a sério, que em trinta dias eu estaria na Suíça, fazendo-lhe companhia nas recepções da FIFA? (...) não, eu apenas agi como um homem (...). (Tezza, 2016: 178-180)

Nesta parte do romance, a expectativa de final pode delinear-se como um daqueles tantos filmezinhos açucarados de sessão da tarde, protagonizado por uma mocinha espevitada, que se deixa envolver pelas artimanhas do coração. Evidentemente esta é uma falsa expectativa, uma vez que há muito mais profundidade no romance do que sua leitura linear permite inferir. O envolvimento sexual, por exemplo, aponta para o amadurecimento da personagem e da sua liberdade de escolha: "O sexo, finalmente, perdeu o mistério e o segredo, ela poderia dizer agora, eu estou madura, o sexo é apenas mais uma variável da vida e não está necessariamente atrelado a nada - apenas ao desejo, esta coisa volátil, venenosa e infiel." (Tezza, 2016: 178)

Passados os dias como intérprete da FIFA, Beatriz volta à sua rotina, às suas reflexões e à tradução do texto de Xaveste, mais uma das questões abertas que o romance deixa ao seu leitor: o autor catalão escreve em espanhol? Ou talvez escreva em catalão e tenha sido traduzido para o espanhol, considerando o conflito entre as nacionalidade entre Catalunha e Espanha? Neste caso, Beatriz estaria se dedicando a uma retradução, uma atividade considerada arriscada e que é, sem sombra de dúvida, até hoje, posta em suspeição pelos tradutores profissionais. Contudo, estes temas não são abordados na obra. Estas questões parecem não preocupar a protagonista que, até o final do romance, continua crendo nas concepções tradicionais sobre o tema:

Beatriz suspirou, cansada, sentindo um véu de dor de cabeça, e conferiu as páginas que faltavam - este livro não acaba nunca! Releu o longo parágrafo - tudo parece muito abstrato, ela diria ao Chaves, mas a tradução continuava lhe parecendo boa e sonante, fiel ao original. Tradutor não pensa; tradutor traduz. E ela deu uma risada (...) Eu só preciso de Heiddeger, mas quando você puxa um fio da filosofia você vai levantando um labirinto de referências, uma rede sem fim que se estende pelo infinito até Zoroastro. (Tezza, 2016: 192)

Ao considerar que "tradutor não pensa; tradutor traduz", Beatriz declara, talvez inconscientemente, que traduzir é uma atividade mecanizada e automatizada. Tal declaração a aproxima, uma vez mais, das concepções mais tradicionais, que consideram o tradutor um mero reprodutor de mensagens o que a sintoniza uma vez mais com a falta de formação específica. Entretanto, quando a protagonista encontra-se com Julinha, uma ex-colega de faculdade, explicita-se sua formação em Letras.

A confusão de Beatriz entre o espaço público e o privado não é sintoma de falta de profissionalização, como inicialmente se suponha. Mais do que isso, é uma característica do sujeito pós-moderno, ansioso pela novidade, movido pelo imediatismo e pelo descarte. Sua relação com Erik é uma exemplo disso. Para não correr o risco se sentir preterida e ter de enfrentar a verdade, Beatriz sai do hotel, ainda mesmo antes de Erik acordar. Acaba, 
na pressa de fugir do espelhamento que o confronto com a realidade produz, esquece ali os seus óculos. Metaforicamente seria possível compreender os óculos com a correção da visão turva, nublada e difusa, também qualidades elencadas como índice da pós-modernidade. E a correção, embora identificada, fica para o futuro: "Amanhã eu passo no hotel e pego os óculos”. (Tezza, 2006: 203). Os encontros, a partir de então, passam a ser exclusivamente profissionais e em público.

No mesmo sentido, o envolvimento sexual de Beatriz com Erik talvez possa ser avaliado como uma liberdade concedida a um europeu em visita ao Brasil. Neste sentido, pejorativamente, o papel de "intérprete informal" se confundiria com o de acompanhante. Assim sendo, a imagem que o romance difundiria e/ou reforçaria seria deliberadamente negativa. Mas, como se trata de uma mulher contemporânea, que assume sua vida, suas escolhas e as consequências delas, a confusão não se sustenta.

\title{
Considerações finais
}

O texto apresenta a tradutora com toda a sua complexidade: inserida na sociedade de consumo, devastada por ela, confusa diante das infinitas possiblidades de modos de vida e ansiosa em relação aos seus compromissos - especialmente os financeiros. Como mulher, oscila entre vários tipos de relação, desde a mais estável - com alguns componentes de abusividade - até outras paralelas.

\begin{abstract}
Não, não me livrei do meu trabalho ainda, ela pensou, eu tenho que voltar à tarde, recuperar meus óculos e devolver o executivo ao aeroporto de onde ele veio e ao qual pertence, provavelmente para nunca mais, mas preferiu não pensar nisso - um desejo de entrar logo em casa e passar o início da semana a limpo, a vida nova, uma segunda-feira poderosa, sem Donetti, nem ninguém, e enfim terminar a tradução e conversar com Chaves, demoradamente. Por que eu caí nessa esparrela sentimental? (...) Seja firme, minha filha, o pai lhe disse uma vez quando ela chorava, criança, por uma bobagem qualquer. (...) (Tezza, 2006: 178)
\end{abstract}

Subjaz, ainda, a possibilidade de uma nova relação, a instaurar-se quando se terminem os trabalhos: o da FIFA e a tradução de Xaveste. A amizade com Chaves, o editor, começa a ganhar destaque e, de certa maneira, justificar os ciúmes de Donetti. Em conversa por Skype, Beatriz repete a seu editor que "tradutor não pensa, tradutor traduz", agora em tom jocoso e cúmplice. Na ocasião, Beatriz lê fragmentos da tradução para o editor, para que ele a ouça e sinta de "soa bem". Em seguida, comentam a possibilidade de que ela vá a São Paulo.

Sim, venha para São Paulo - disse-lhe Chaves, depois de elogiar a tradução, já deu para sentir só por uma lida em diagonal que ficou muito boa, agora é só enviar para a preparação dos originais. Mas tenho outros projetos para você, o que ela entendeu como ambivalência deliberada, seria legal a gente se encontrar pessoalmente (...) (Tezza, 2006: 190)

Não apenas a narrativa entrecortada e fragmentada, que desacomoda o leitor e pode vir a sacudir algumas de suas verdades - como a crença na leitura linear - mas também a mistura de temas e o aproveitamento sagaz dos fatos da realidade, fazem de A tradutora uma obra de instigante valor para analisar a segunda década do século XXI, sobretudo depois do melancólico final do Campeonato Mundial e dos caminhos político-sociais que se desenvolveram a partir de então. É importante ressaltar, por outro lado, que há outros aspectos relevantes no romance que ficaram à margem deste estudo. Especificamente sua dimensão sócio-política, enfocada 
nos resultados da era Lula e na reeleição da presidenta Dilma não receberam atenção, tendo em vista que não têm relação direta com o recorte metodológico escolhido.

O texto é inovador não apenas por sua temática e na designação da protagonista, mas também por propor-se a discutir com o grande público um assunto que sequer é suficientemente discutido entre os especialistas da área. Talvez a profissão da protagonista não seja vista ainda, pelo público leigo, como importante para a compreensão da narrativa. Ou talvez a narrativa fragmentada não consiga encontrar eco no grande público, ainda sensível a textos narrados cronologicamente.

Finalmente, é possível afirmar que o romance é uma grande metáfora sobre o fazer tradutório: a multiplicidade de vozes, o dialogismo (as "conversas" entre os textos) as concepções sobre o ato de traduzir e suas consequências, as relações estabelecidas durante o processo tradutório. Beatriz tem diante de si uma série de escolhas. De ordem afetiva e profissional, especialmente. Experimenta cada uma delas, às vezes com método, outras vezes de forma empírica. Testa soluções e combinações. Tenta encontrar aquela que lhe parece mais adequada à questão a ser resolvida. Tateia, se decepciona, se arrisca, mas não abre mão de participar do jogo. Não se conforma com os silêncios:

Confesse, Beatriz, ela disse a si mesma: você está com medo de abrir este envelope, porque teme se enredar novamente, e no mesmo momento ela pegou o canivetinho de cortar papel que sempre deixava na gaveta. Você é tão cuidadosa para abrir envelopes (...) mas isso lhe soou como velhice antecipada (...). E depois, quando as pessoas se amam, que importância isso tem? (Tezza, 2016: 194)

Ainda segundo esta proposta de leitura metafórica, o amor poderia ser entendido como a suprema harmonia entre a dessemelhança linguística, histórica e cultural. Avesso às convenções o amor põe-se em marcha no início do processo tradutório e sequer se detém diante de possíveis traições. Muito mais do que emprestar beleza à linguagem, as metáforas servem, algumas vezes, para dizer o indizível, talvez porque ainda não saibamos definir com clareza o nosso objeto de pesquisa e estudo. Uma vez mais, a literatura nos dá a resposta para as perguntas que não conseguimos elaborar.

\section{Referências Bibliográficas}

ARROJO, Rosemary. Tradução, desconstrução e psicanálise. Rio de Janeiro: Imago, 1993. BAKHTIN, Mikhail. Problemas da Poética de Dostoiévski. Tradução de Paulo Bezerra. Rio de Janeiro: Forense Universitária, 2008.

BAUMAN, Zygmunt. Vida para consumo: a transformação das pessoas em mercadoria. Rio de Janeiro: Jorge Zahar Ed., 2008.

BERMAN, Antoine. A prova do estrangeiro. Bauru: EDUSC, 2002.

HALL, Stuart. ¿Quién necesita “identidad”? In: Hall, Stuart y Du Gay, Paul (orgs.)

Cuestiones de identidad cultural. Buenos Aires: Amorrortu, 2003.

JONHSON, Bárbara. A fidelidade considerada filosoficamente. In: Tradução, a prática da diferença. Paulo Otoni (org.) Campinas: UNICAMP/FAPESP, 1998.

MITTMANN, Solange. Notas do tradutor e processo tradutório. Porto Alegre: UFRGS, 2003.

TEZZA, Cristovão. A tradutora. Rio de Janeiro: Record, 2016. 